\title{
The Western Australian Police Headquarters Building Surveillance, Power and the Authoritarian State
}

\section{JON STRATTON}

CURTIN UNIVERSITY

I first came to Perth in January 1990. Like most people since the 1960s I arrived by plane. Curtin University of Technology had made arrangements for me to stay at the Metro Hotel on Canning Highway-a rather invasive building in the International Style among predominantly federation style residential homes. I was driven down Great Eastern Highway, onto the bridge over the bottom end of Shepperton Road that leads into the Causeway across the Swan River, and then onto Canning Highway. I did not turn right and enter the city. Consequently I did not get to pass the Police Headquarters on the other side of the Causeway.

A couple of days later, on a Saturday afternoon, I went to the jetty in South Perth and took a ferry into the city. While walking round the empty centre of Perth with its closed shops and lack of cafés I happened to jaywalk at some traffic lights. 'Hey', I heard a cry, 'Hey, you!' The young man who had crossed with me stopped and turned. I did also, feeling like the character in Louis Althusser's description of interpellation. ${ }^{1}$ The policeman came running over. 'What do you two think you were doing?', he asked. An answer seemed redundant. The policeman then turned to my companion in transgression and asked what his name was, where he lived and if he 
had been in trouble with the law before. Sheepishly the man replied that he had once been caught shoplifting. Obviously he was a criminal of the highest order. The policeman told him that if he was caught jaywalking again he would be prosecuted.

Then he turned to me. Why had I done this terrible thing? 'Well', I replied, 'I'm new in Perth and don't know my way around'. 'What's your address?', he asked. 'I'm staying in a hotel', I told him. No fixed address did not seem to go down too well, even with the explanation that I had only been in Perth two days. Next he asked where I had come from. Darwin, I admitted. Then, on the apparent presumption that the only reason I would have jaywalked was because I didn't understand how traffic lights worked, coming, as I had, from such a remote community where, obviously, traffic lights would not exist, he set out patiently to explain to me their semiotics. Following this he let me off with a caution similar to the one he had given my comrade in crime. I continued my educative stroll around the heart of Perth rather bemusedly coming to grips with this experience. Making sense of what had just happened might have been easier if I had earlier been confronted by the Police Headquarters building.

The building housing the Police Headquarters in East Perth, at the eastern gateway to the city of Perth, was opened in $1975 .^{2}$ Through the fifteen years it took to be constructed Western Australia, primarily under two Liberal premiers, David Brand and Charles Court, was transformed from a state dependent on an agrarian economy into one founded on resource extraction and export. Paralleling this development, Western Australia's government became increasingly authoritarian and its policing was more and more tied to the needs of that government. All this is expressed in the positioning and architectural style of the Police Headquarters. Michel Foucault has argued that surveillance was a key aspect of the modern world. The Police Headquarters can be read also as expressing the form of mass surveillance that typified modernity, a surveillance which can easily work in tandem with the authoritarian state.

Elaborating on Foucault's understanding of power, Patrick Joyce and Tony Bennett explain that power might be conceived of 'as omnipresent, and as constantly ebbing and flowing, collecting and dispersing, in changing combinations and arrangements' ${ }^{3}$ In their edited collection, Material Powers, Joyce and Bennett bring 
this concept of power into alignment with the material. As they write: 'It is ... a matter of taking account of the distinctive kinds of effectivity that material objects and processes exert as a consequence of the positions they occupy within specifically configured networks of relations that always include human and nonhuman actors.'4 In Perth, for more than thirty years, the Police Headquarters building acted as the visible expression of police power, power that was increasingly organised in a hierarchical fashion and linked to the practises of the state.

It might be surprising that nothing has been written previously about the Police Headquarters building. Its importance in Perth's built environment is unquestionable. However, this absence becomes more understandable when we realise that there is little work that critically engages with the Western Australian experience; no commentary on the transformations in Western Australian politics, little cultural analysis of the importance of mining, indeed, as we shall see, little work that links the political order of the state with the built environment. This lack of critical engagement is pervasive. The dominant narrative of the cultural imaginary is of success against the odds, and against the forces of control and depredation manifested in the eastern states and the federal government. Such a narrative discourages critical commentary as being negative and encourages a generalised acceptance of the Western Australian experience manifested in the often-voiced statement that Perth is a good place to bring up kids. ${ }^{5}$ In this analysis of the Police Headquarters building I shall touch on some of the changes that have taken place in Western Australia, and in Perth, since the 1960s and examine their connections with Perth's built environment.

\section{-Police BUILdings AND POLICING In PERTH}

The Western Australian Police Headquarters building is a nine-storey structure designed in the International Style. It is curvilinear; a concave line that looks towards the Causeway, placing the entrance in the bay of the curve. In later International Style buildings such as this a curved form was not common but neither was it extraordinary. For example, in Sydney the AMP high-rise building, situated at Circular Quay and finished in 1962, has a concave form. Such a curve was supposed to soften the hard edges of International Style structures. However, interpretation is in the eye of the beholder and is heavily influenced by context. To me, the concave 


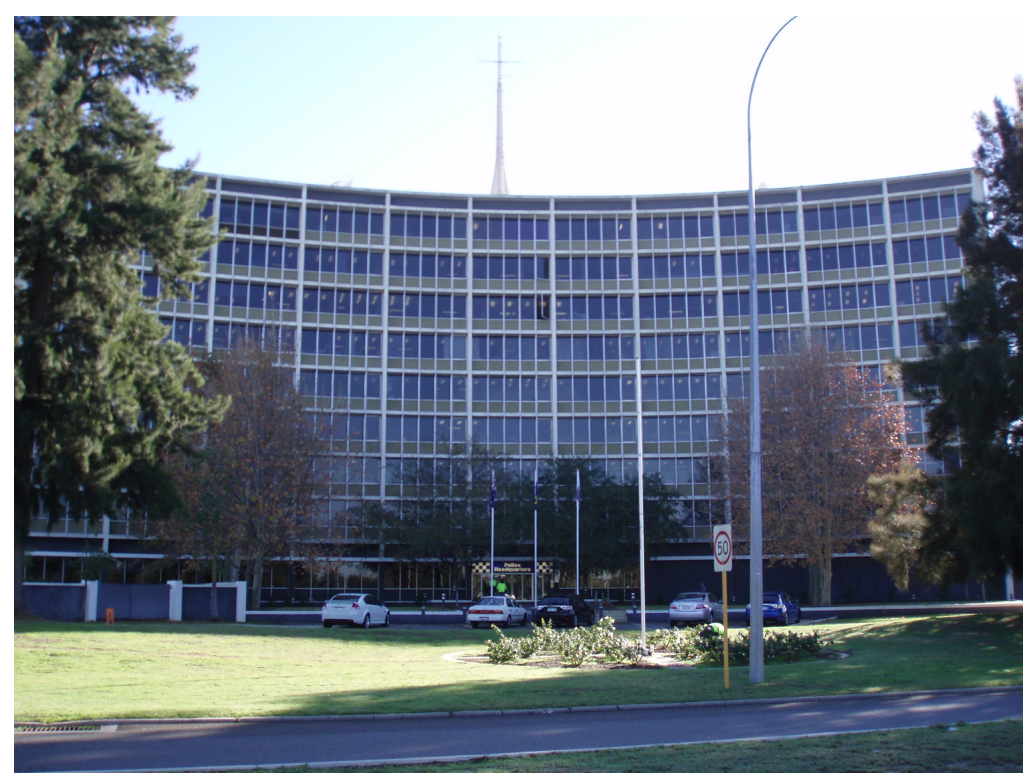

Figure 1: Police Headquarters also known as the Western Australian Police Service Complex

Source: Courtesy of the Heritage Council of Western Australia

form of the Police Headquarters suggests more than anything a crouching creature enfolding its prey.

One reason given for the Police Headquarters' concavity was that it was supposed to compliment a circular building which would have been the Police Courts. This, though, was never built. The Headquarters' external appearance was imposing:

The ground floor, only, has a black granite plinth and black mosaic tiled columns. The upper floors had a finish of exposed aggregate render to columns and floor slabs. Between columns and floor slabs were situated clear anodised aluminium windows glazed with grey glass. ${ }^{6}$

The final design was accepted in 1972 and building was completed in 1975. The heritage documentation explains the place 'demonstrates the shift in the design of office buildings from the glass-curtain walls prevalent in the 1950s towards more the environmentally responsive buildings in the 1960s.' The point being made here is not that the Police Headquarters building can be read as sensitively engaging with its local environment; indeed as we shall see it precisely does not do this. Rather, because the building does not have glass-curtain walls it relates better to Perth's hot, sunny summers. At the same time, where glass-curtain walls can give an impression of openness between inside and outside, the walls and windows of the Police 
Headquarters suggest more a division between the police working in the interior and the people entering and leaving the busy roundabout beyond the building's entrance.

Besides the Police Headquarters building, the site contains two other police buildings. One is a two-storey auditorium and amenities block. The other is a major construction, the East Perth Lock-up and Central Police Station. This is a threestorey building placed behind the Police Headquarters with an entry onto Hay Street. It was opened in 1965, ten years before the Police Headquarters building. The East Perth Lock-up and Central Police Station lies directly opposite one of Perth's major sporting venues, the cricket ground of the Western Australian Cricket Association, known as the WACA. This positioning of the WACA at the eastern entry to the city acts as a constant reminder of the centrality of sport to the Western Australian lifestyle-situated next to the Police Headquarters, the WACA could also be read in terms of the way sport acts as a distraction from the increasingly authoritarian role of the Western Australian executive and police, a form of panem et circenses.

On top of the Police Headquarters, and placed centrally, is a radio aerial. With its supporting struts it is reminiscent of the image used by RKO Pictures as their logo from the 1930s onwards. This has an aerial placed on top of a globe of the world. Out of this aerial there is a corona of what appears to be jagged lightning bolts signifying not just radio communication but the modern excitement of new

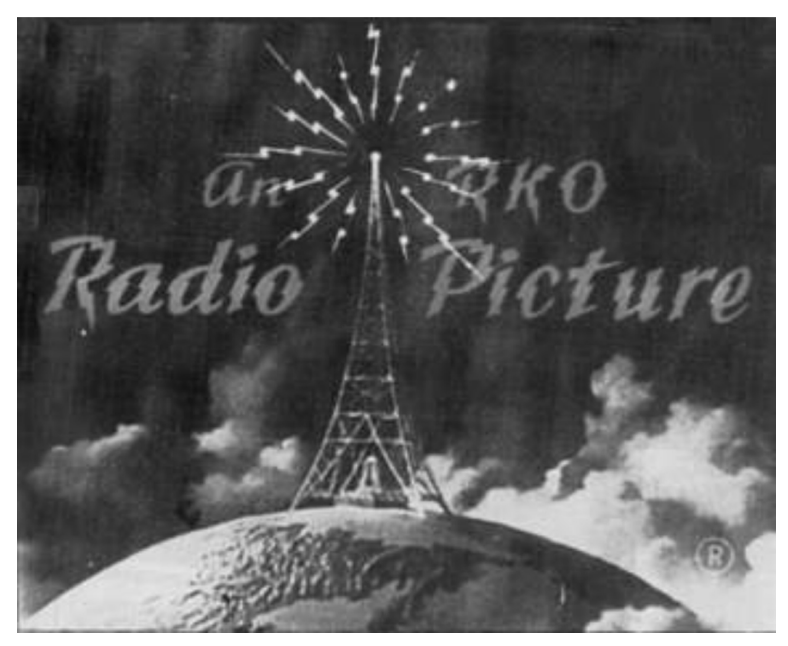

Figure 2: Image used by RKO Pictures as their logo

Source: 'File:Rko.JPG', in Wikipedia, 1936-55, RKO Pictures LLC ${ }^{7}$ 
technologies of communication. The aerial on top of the Police Headquarters is a visual signifier of the modernity of the building. When it was constructed the police praised it for having the most up-to-date communication technology available. ${ }^{8}$

The first suggestion that the present location should be used for a Police Headquarters was made in 1959 by the then Commissioner of Police, James M. O'Brien. At this time the police were administered out of a group of buildings centred on Roe and James Streets in what was then still known as North of the Line-the area north of the railway line now known as Northbridge and identified as the city's entertainment precinct. When the police moved from North of the Line first to the old Perth Girls' School on the high ground at the beginning of Wellington Street and then to the Police Headquarters near the Causeway it represented a fundamental shift in the form of policing in Perth, and Western Australia generally.

The first centre for Perth police had been the Waterside police station near the Swan River on Bazaar Street. However, as Peter Conole argues, the population expansion that was a consequence of the gold rush of the 1890s moved Perth's centre northwards. The police followed and in 1897 they took over a number of land allotments between Roe, Beaufort and James Streets. ${ }^{9}$ In September 1901 a lock-up was opened on Roe Street. Four years later, a police barracks was opened on James Street. This was to become the police administrative centre until the move in 1963 to the Perth Girls' School building. The James Street barracks had two storeys. Its heritage documentation describes it this way:

the place, viewed from the exterior, is a fine, simply rendered example of Federation Romanesque style stone construction architecture. With its pillow shaped rock faced Donnybrook sandstone construction walls, symmetrical arrangement of pavilions, arcades and fenestration, the building makes a strong and simple statement, while retaining a domestic scale. 10

There are two elements in this description to which we should pay close attention. The building presents as strong and simple. Even the Romanesque style was understated. Again, like the Roe Street lock-up, the Police Barracks building could be read by the local population as impressive but not assertive in its form. Indeed, as the description tells us, the building retains a domestic scale. This is most definitely 


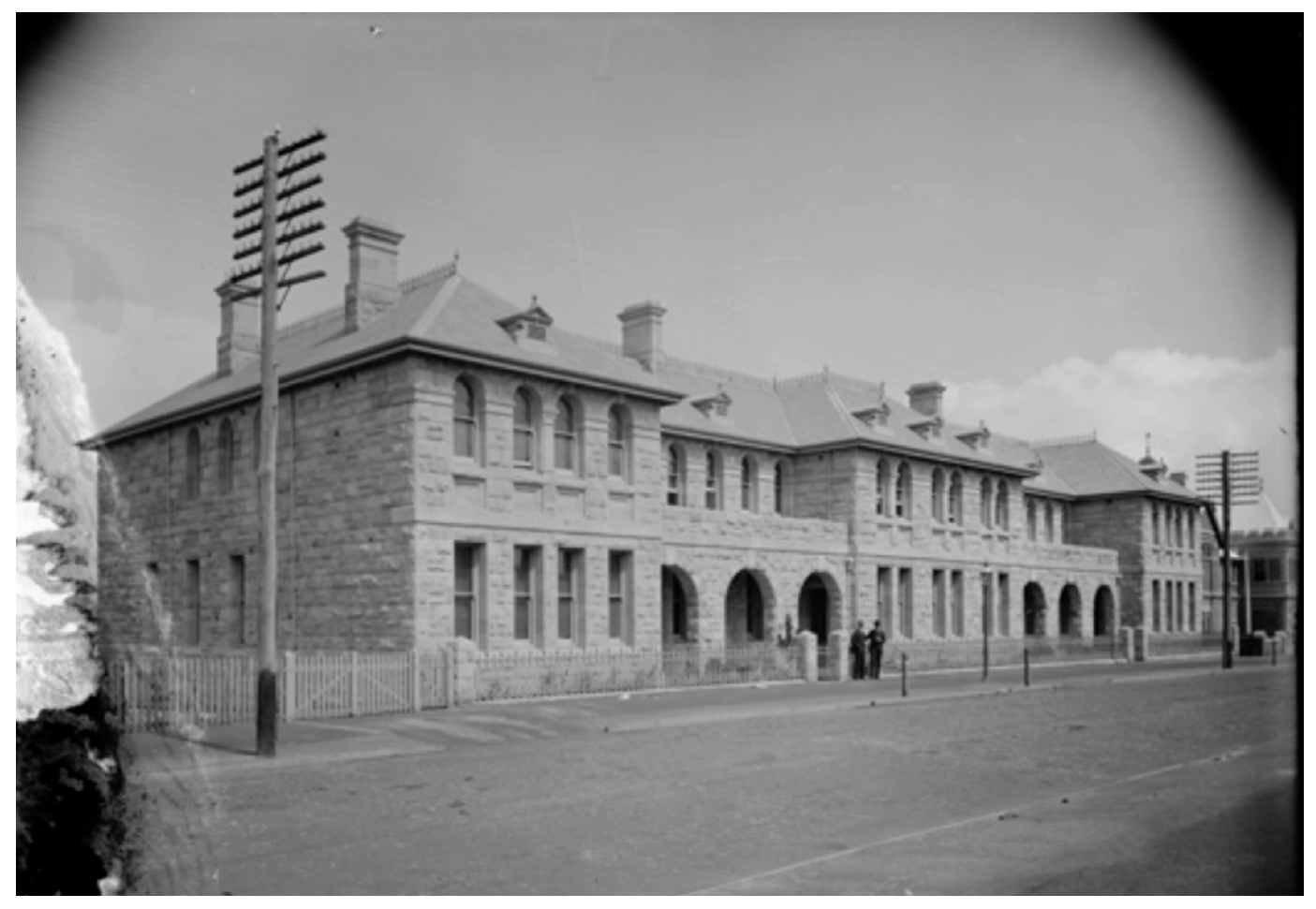

Figure 3: Police Barracks, c. 1907

Source: Passey Collection, 5323B/1446. Courtesy of the State Library of Western Australia ${ }^{11}$

not something that could be said for the Causeway building nor, for that matter, for the Perth Girls' School building.

The Perth Girls' School was built in 1936 in the Stripped Classical style to service around five hundred pupils. This architectural style gives the building a sense of grandeur. As the heritage documentation notes, this is a 'rare use of a style more often associated with parliamentary buildings, and government departments than with state schools'.12 With declining enrolments the school was closed in November 1962. The building of the East Perth Police Headquarters had been placed on hold in 1960, so from March 1963 the police occupied the Girls' School building. The building's architecture, which had been a statement of the resilience of Perth in the immediate aftermath of the Great Depression, now served to enforce the power of the police.

On the corner of Wellington and Plain streets, the building 'occupies a commanding hillside position with views of the Swan River. Despite the encroachment of high rise buildings in the vicinity, the former Perth Girls' School still dominates the landscape.'13 In other words, unlike the James Street barracks 


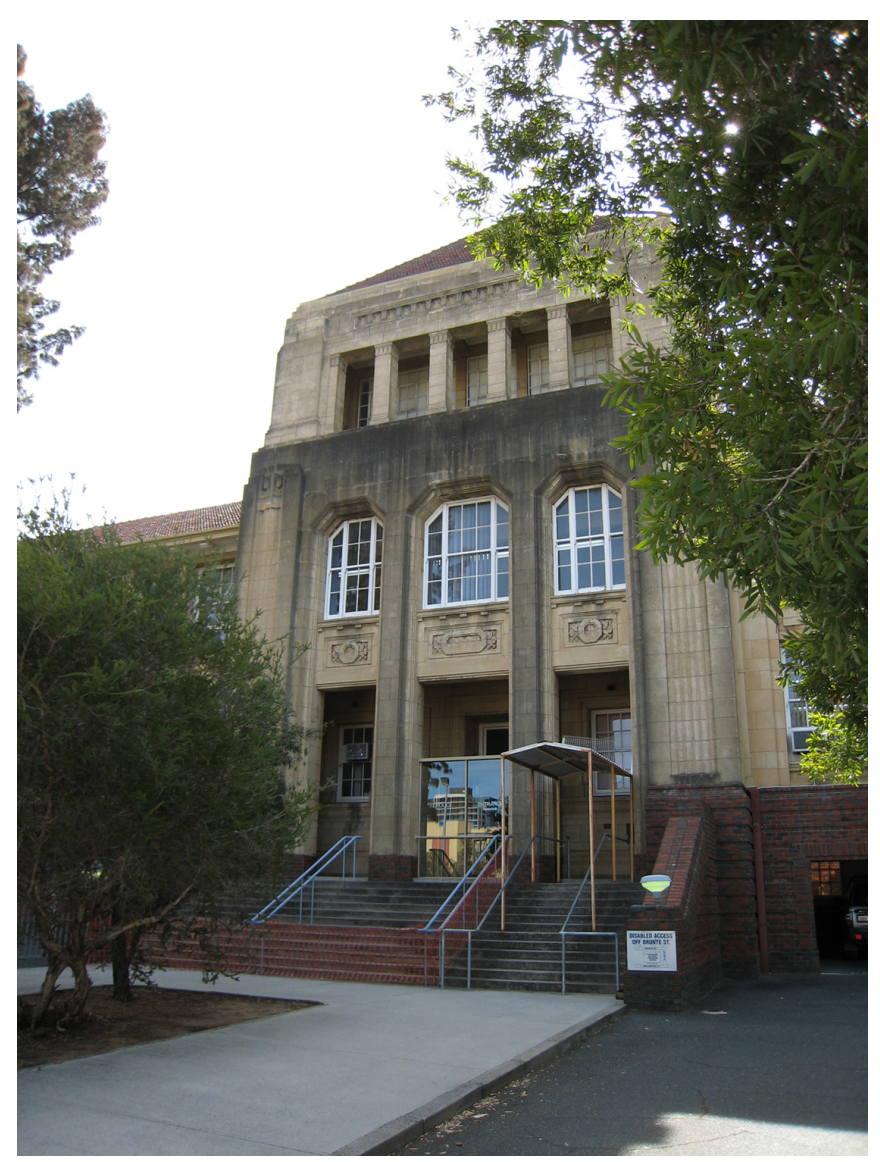

Figure 4: Perth Girls' School/Police Headquarters/Traffic Branch, c.1990s

Source: Photo by David Treloar, courtesy of the Heritage Council of Western Australia

from whence the police had come, the Perth Girls' School building stands out in its built environment. Positioned on the high point of the hill it remains, even with the high-rise buildings now built in the surrounding area, an imposing building. It overlooks its local area just as the Police Headquarters commands a view along the Causeway. The Perth Girls' School building continues to be utilised by the police. Now it houses the Police Traffic Branch.

In the development I have outlined we are witnessing an architectural alienation that reflects the movement of 'police' from members of the settler community to a distinct entity increasingly imposing, as we shall see, not so much the law but the will of the executive. This does not mean that the early police were accepted by the community or policed in the interests of the community per sethat is policing was always class, and race, related. ${ }^{14}$ Rather, it means the police 
functioned from within settler society. As Christopher Corns puts it, commenting on the historical changes that have occurred in the positioning of the police within Australian society:

the form of policing has ... undergone a metamorphosis with a growing disjunction between the police and the policed. In many respects the personal, direct interrelationship between the individual police officer and the community has been replaced with anonymity, impersonalisation, and a sense of 'faceless' policing. 15

When police operations were centred in North of the Line, they were close to much of Perth's criminalised activity. To take one example, they were neighbours to the notorious Roe Street brothels. Conole notes:

it was at times a source of some mirth to the public that [these] brothels operated not very far from the Police complex. In reality it was a convenient arrangement for the containment of the oldest profession and the deterrence of major crime figures who might have liked to move in on the racket. 16

With the move to the Perth Girls' School building, and then to the Police Headquarters, such embedded policing of the settler community became impossible. I emphasise settler here because the police acted as an occupying force in the experience of the Western Australian Indigenous people. As Chris Cunneen argues, 'Colonial police participated in the war against Indigenous people and were directly engaged in violent repression and colonial expansion.' ${ }^{17}$ We shall see later that this had a long-term effect on, among other things, Indigenous incarceration rates and attitudes towards Indigenous rights, especially in northern Western Australia which was the part of the state most affected by the expansion of resources development from the early 1960 s onwards.

The long-term transformation from what could be called embedded policing was by no means unique to Perth or to Australia. In recent times, the shift has been even more apparent. Referring to an argument made by Paul Gordon in 1987, Stephen Hester and Peter Eglin write: 'In the case of the United Kingdom it is pointed out by Gordon, for example, that "the shape of British policing has changed dramatically, if not fundamentally", since the late 1960s and early 1970s.'18 They explain: 'A major focus of attention for critical criminologists and sociologists of law 
has been on what [Stuart] Hall calls the "drift to the law and order society". That is, recent developments in the character of policing in both Britain and North America have been the subject of Marxist analysis wherein a connection has been made between increasingly authoritarian measures of policing on the one hand and laissez faire economic policies on the other.'19 In Western Australia, as in Queensland-that other Australian state where mining is of huge importance to the economy-this 'drift' began earlier and was associated with the push for the development of primary industries, which itself took place in the context of an attempt to install a laissez faire approach to land exploration and exploitation, rather than the evolution of neoliberal capitalism.

One expression of this change in the form of policing can be found in the increase in the numbers of people imprisoned. James Thomas and Alex Stewart, in Imprisonment in Western Australia, remark that during the 1960s there was, 'a considerable increase in the numbers in prison. The daily average rose steadily throughout the decade and continued to do so into the 1970s. In 1963-64 the daily average was $856.42 \ldots$ In 1972-73 the daily average was $1416.94 .{ }^{\prime 20}$ To some extent this gross increase can be accounted for by the rapid growth in Western Australia's population which, because of the resources boom, increased from around 736,000 in 1961 to over a million a decade later. However, the increase in incarceration was disproportionate. In 1967/68 Western Australia's rate of imprisonment stood at 117.8 per 100,000 people. At that time this was easily the highest rate of any Australian state. New South Wales' incarceration rate, for example, was 83.8 per 100,000. Queensland, where Joh Bjelke-Petersen, whose repressive regime bore many similarities to that of Charles Court in Western Australia, came to power in 1968, had an incarceration rate of only 62.4 per 100,000 in 1967/68.21 By 1999 Western Australia's incarceration rate had increased to 208.3 while Queensland's had jumped to 190.5. For comparison, New South Wales's rate in that same year was 147.4 per 100,000, an increase but still very significantly lower than Western Australia's and Queensland's rates.

One element of these figures that has to be noted is the very high proportion of Indigenous prisoners. In the late 1970s, while constituting only 3 per cent of Western Australia's people, Aborigines formed 32 per cent of the daily prison population. Quinton Beresford tells us that this was 'a proportion that was much 
higher than other Australian states'.22 So, by the time the Police Headquarters building was fully functional, not only did Western Australia have the highest general incarceration rate in Australia, but the rate for Indigenous Australians was also proportionally much greater than in any other Australian state-though it needs to be acknowledged that the Northern Territory, with a much greater proportion of Aborigines in its total population, had higher rates.

-David Brand, Charles Court And deVElopment

David Brand had become premier in 1959, the same year the plan for the Police Headquarters in East Perth, near the Causeway, was first proposed. That year he also started pushing strongly in Canberra for the lifting of the ban on the export of iron ore which had been instituted in 1938. The story goes that Lang Hancock, at that time a pastoralist, had found the Hamersley Range iron ore deposit in the Pilbara by accident in 1952. He then started lobbying for the ban to be removed. With the premier onside, they succeeded in December 1960. This was the beginning of Western Australia's first post-World War II resources boom. In addition to iron ore, nickel was discovered in 1966 at Kambalda and in 1969 at Mount Windarra. It is important to remember that, like later booms, this one was export-driven. William Lines places this development push in context:

Until the 1960s ... when the expanding Japanese economy and steelmaking industry required massive supplies of raw material, no one wanted the ore. But with assured Japanese demand, transnational capital opened up major iron ore fields in the Pilbara and began mining nickel, salt, mineral sands, bauxite, oil and gas elsewhere in the state. ${ }^{23}$

Brian Head tells us, 'the mineral export industries began to have a major impact on the WA economy from the mid-1960s'24 and, indeed, 'in 1968, Western Australia ceased to be a "claimant state" (for the purpose of Commonwealth Grants Commission enquiries into the financial disabilities of the small-population states).' ${ }^{25}$ So, the development-driven change in Western Australia's financial circumstances occurred at the same time that a change was taking place in the role of the police.

The courting of multinational companies had begun earlier. Brand had entered politics through a by-election in 1945, winning the seat of Greenough for the Liberal 
Party. When the Liberals under Ross McLarty gained power in 1949, Brand became Minister for Housing, Forests and Local Government. A year later, as Minister for Works, he supported Russell Dumas, a senior public servant and early supporter of the Ord River irrigation scheme in the Kimberley during the 1940s and 1950s, in negotiations that led to the establishment of the Anglo-Iranian Oil Company's refinery at Kwinana, south of Perth (Anglo-Iranian became British Petroleum in 1954). Subsequently, BHP's steel-rolling mill and Cockburn Cement's cement works were established in the same area.

Throughout Brand's twelve years as premier, from 1959 to 1971, Charles Court was Minister for Industrial Development and the North-West. Court was in charge of negotiating the mining deals for the Pilbara iron ore projects. Brand was defeated in the 1971 election and, in 1972, retired from leadership of the Liberal Party. Court took over and in coalition with the Country Party won the 1974 election. Court was, if anything, more development-oriented than Brand. On his watch not only was there expansion in the mineral extraction industries but Court also laid the basis for the North West Shelf gas project, a massive resource development that accounts for more than 40 per cent of Australia's gas and oil production. To gain the confidence of multinational corporations with the financial backing to invest in the minerals and energy projects Court needed Western Australia to appear to be safe and placid, untroubled by strikes and with pacified and submissive workers. As Lines writes:

The state, however, did not regard the creation of employment as a priority; on the contrary, development should be capital intensive, designed to make people obsolete. As Court explained in 1966: 'We must ask firms which approach us, not how many men can you employ but how few? How efficient can you be, how much can you mechanize and automate?'26

Court did not see a role of his development projects as providing work for Western Australia's workers.

To these ends Court started putting in place a range of limitations on the rights of Western Australians. It was the duty of the police to enforce these restriction. This enforcement was much helped by Court having a politically friendly police commissioner. In September 1975, almost eighteen months after Court became premier, and five months after the Police Headquarters building was opened, Owen 
Leitch was made Police Commissioner. In her biography of the Communist and union leader Jack Marks, Jolly Reid describes Leitch in this way:

It was no secret he admired Sir Charles Court as Premier. It was no secret he distrusted 'the reds.' And he wasn't afraid to go public implicating anybody with Left leanings as loony, unlawful, or worse, as a menace to society. His commission was above everything authoritarian. His style was belligerent, tough and controversial. ${ }^{27}$

Leitch was Court's man.

In November 1975 Court made his first move against the unions and others that he thought of as troublemakers. He banned assemblies in Forrest Place. Named for the first premier of Western Australia, Forrest Place, in the centre of the city, had a long history as an open space used for political and other rallies. Banning assemblies here meant any rallies would have to be held outside the city. In his history of the Western Australian police force, Peter Conole tells us that:

Leitch promptly wrote to various organisations supporting the decision, stating there was less risk of people being injured or traffic flows interrupted and better provision for security, with appropriate amenities on hand, if the Esplanade were used instead. ${ }^{28}$

The Esplanade, a stretch of greensward by the Swan River, is outside the built environment of the city and a rally there would have much less political impact than in the traditional, urban space of Forrest Place. Court, though, was just getting started.

A year later, in January 1977, Court amended Section 54B of the Police Act. The key change was that any organisation wishing to assemble or march anywhere in Western Australia had first to get permission from the Police Commissioner. This amendment effectively stifled political protest, as permission would not be given to any group the Police Commissioner considered a threat to public order. The amendment provoked a great deal of concern and unrest, especially as a meeting was defined as three or more people. Jenny Gregory adds that: 'Justifying the legislation, Premier Court later said that in an era of strikes, protests and demonstrations, society's most dangerous enemies were political or social activists.'29 Leitch was prone to commenting on these so-called threats in the Police Department Annual Reports. Echoing his premier, in 1978 he wrote: 
Demonstrations also are another area of police concern. They are constant, and are over a variety of social and political issues and philosophies. This year has been no exception to previous years. At many of them the same fanatical and professional demonstrators are to be found. They promote and agitate for breaches of the peace, and then feast on the melee they have created. ${ }^{30}$

Section 54B was not revisited until the Labor government of Brian Burke passed the Public Meetings and Procession Act 1984.

Other legislation to suppress dissent followed. In 1979 the Essential Foodstuffs and Commodities Act was passed. Lines sums this up as 'essential services legislation [that] outlawed strikes in those industries most essential to the operations of transnational capital-fuel, energy, power.'31 Also in 1979 parliament passed the Government Agreements Act. This seemingly routine Act, which established protocols for government contracts with industry, also contained clauses that 'gave police special powers to arrest people who occupied land designated in any development legislation (or who hindered any activity pursuant to development legislation).'32 Court was opening the way for almost unhindered exploitation of Western Australia's resources through legislation which placed the police at the forefront of political action. Indeed, as Lines caustically notes: 'As a demonstration of impartiality, the police acquired anti-riot equipment, including two armoured cars, and trained with the Army's Special Air Services regiment.'33 Under Leitch the police willingly colluded in the evolution of Court's authoritarian state.

One of the best examples of the politicisation of the police through Court's determination to allow little, if anything, to stop resource exploitation was the Noonkanbah dispute. This also illustrates my earlier point that the police were used as, and experienced by Indigenous Australians as, an occupying force. Indeed, as Lines puts it: 'The prospect of conquest, of exerting human dominion in regions hitherto only inhabited by Aborigines, pastoralists and sheep, overwhelmed any other consideration.'34 Noonkanbah is a pastoral property in the Kimberley on the Fitzroy River inland from Broome. In 1976 the land was bought by the Aboriginal Land Council on behalf of the Kadjina and Yungngora peoples. In spite of opposition from the landowners an American company, Amax, was determined to drill 
exploratory wells looking for oil. The problem was made worse by these potential wells being located very close to Indigenous sacred sites. Court's government was determined that the drilling should go ahead. Finally, in August 1980 Court authorised a drilling rig, guarded by police, to be driven from Perth to Noonkanbah. Steve Hawke has described the situation:

The drilling rig belonged to a subsidiary of Colonial Sugar Refineries (CSR), one of Australia's largest companies. It was the subject of trade union bans, and manned by a specially recruited 'scab' crew, and most remarkably it had been temporarily taken over by the State Government. The Minister for Mines, not the exploration consortium, was the legal driller of the well.

The rig was brought to the site in a two-thousand kilometre convoy of over fifty trucks with specially issued numberplates, and many of the drivers were wearing face masks to conceal their identities. It was escorted by a large contingent of police, with logistic support provided by the State Emergency Service. The convoy's journey north was marked by demonstrations and arrests and intense media coverage. 35

No oil was found. As Paul Kaplan writes from the vantage of 2010: 'The massive police operation against a defenceless, small Aboriginal community at Noonkanbah looked like a scene from Apartheid South Africa and there was a huge outcry in WA, nationally and internationally.' 36 At the drilling site alone around fifty Indigenous and non-Indigenous people were arrested.

We can see how, as Western Australia became increasingly focused on development through the Brand and Court governments, so policing became increasingly authoritarian and, rather than protecting all members of the state, came to work in the interests of government and the multinationals with whom government was doing business. The Police Headquarters across from the Causeway was planned in the early days of Western Australia's transformation into a development economy and finally opened as Court initiated a new phase in that expansion. The building's International Style expresses well the new role of the Western Australian police-though it should be added that it was a relatively late entrant in the rebuilding of central Perth in this style. 
The style that became known as the International Style began in Germany and France, where, promoted by Walter Gropius and Le Corbusier, it was established as the modernist style which rejected all traditional elements and was founded in the idea that form should follow function. The style arrived in the United States in the early 1930s where, in an essay for a catalogue for the Museum of Modern Art, Henry-Russell Hitchcock and Philip Johnson renamed it the International Style. Tom Wolfe writes that Hitchcock and Johnson:

gave no indication that the International Style-and their label caught on immediately-had originated in any social setting, any terra firma, whatsoever. They presented it as an inexorable trend ... The International Style was nothing less than the first great universal style since the Medieval and Classical revivals, and first truly modern style since the Renaissance. ${ }^{37}$

As Darryl Haltenhauer explains, one key to the International Style is its 'attempt to be ahistorical'.38 We can read this, along with Wolfe's comment, as meaning that buildings in the International Style are not designed to fit in with the architecture around them. They could be anywhere. They are imposed on the local environment and they are experienced as such. Haltenhauer goes to note that, 'the people who used these buildings read them according to cultural conventions, not sharing the architects' code, they saw not natural forms but cold, alienating ones.' ${ }^{39}$ Such a cold, alienating image suited a police headquarters of a police force being remade as an arm of an authoritarian government.

When Brand first agreed to plans for a new police headquarters building near the Causeway in 1960 he was already overseeing the building of the new Eastern Wing of Parliament House, the construction of which had started in 1958. Parliament House had been completed in 1904 on the slope of Mount Eliza, which marks the western gateway into Perth. Previously, Parliament House had looked west, onto Harvest Terrace. The new wing, completed in 1964, reoriented Parliament House so that it now looked over the city. However, the view down St George's Terrace was blocked by the Pensioners' Barracks, a building from 1866 which had originally housed military pensioners from Britain-whose jobs included guarding the convicts sent to work in Perth. 


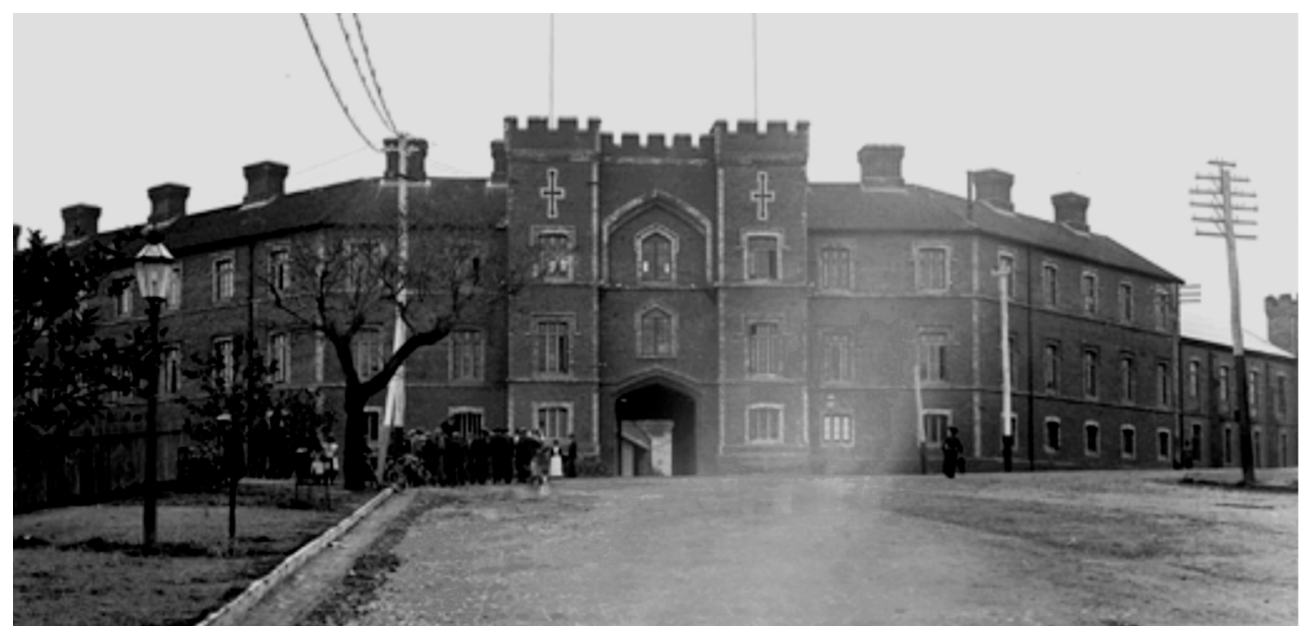

Figure 5: Pensioners' Barracks

Source: Passey Collection, 5323B/491, courtesy of the State Library of Western Australia

Gordon Stephenson was commissioned by the Western Australian government to produce an overall plan for the Perth region. The plan, co-authored with Alistair Hepburn, was handed over in 1955. Stephenson and Hepburn recommended knocking down the Pensioners' Barracks. Brand wanted to do this. Many people, including the new National Trust which had been formed in 1959, opposed the demolition on the grounds that the building was an important part of Perth's architectural heritage. The battle went on for some years. Those arguing for preservation ideally wanted the entire building saved; another suggestion was to save at least the central arch. In 1961 the town planner Margaret Feilman, perhaps with a sense of the increasing authoritarianism of Brand's government attempted to impress upon Brand the grandeur of the Barracks' Arch:

by pointing to the use of arches in Europe, arguing that rather than spoiling the view to Parliament House, its retention would in fact enhance it and symbolise state power ... Radical rebuilding of cities, she suggested, was more in line with autocratic forms of government such as that of Revolutionary France and not the model West Australians, as essentially of

British stock, should be following. ${ }^{40}$

Brand would not be moved by these arguments. It was in 1966, only as a consequence of intense public pressure, that he relented and saved the arch. Brand's imperative was to give Parliament House a clear view down the main business street in Perth. 


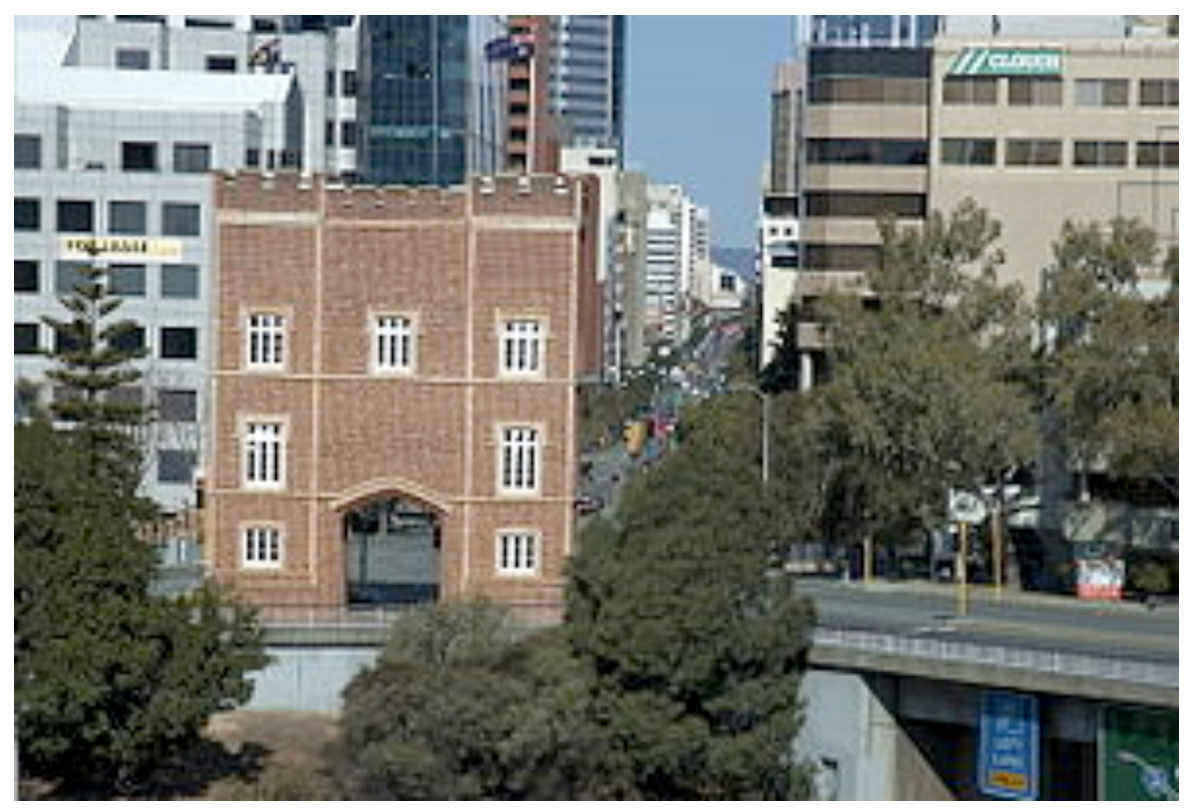

Figure 6: View past the Arch down St George's Terrace, Perth's main business street. Source: Nachoman-au, 'File: Barracks Arch.jpg', in Wikipedia, 15 October $2005^{41}$

The Narrows Bridge was opened in 1959 and the first stretch of the Mitchell freeway leading off from the bridge and past Parliament House, cutting off direct access from the city and splitting the physical connection between government and business, was completed in 1973. In the 1980s two plans were devised to bridge the freeway and provide Parliament House with not only a view down the Terrace but pedestrian access as well. This physical linking provides an apt metaphor for the increasingly close connections between government and business that were a typifying feature of the Brand and Court governments and reached an apogee with the Burke government, elected in 1983, and the subsequent scandal known as WA Inc. As Allan Peachment argues, placing the Burke government's links with industry in a Western Australian historical context:

The focus is nowadays wholly on the executive, especially the office of the Premier which, in the exercise of its power is without peer. The resulting symbiosis between the executive and industrial development has meant that democratic values have been sacrificed. 42

The failure to build the bridging area might even be seen as an expression of the failure identified in WA Inc. 43 


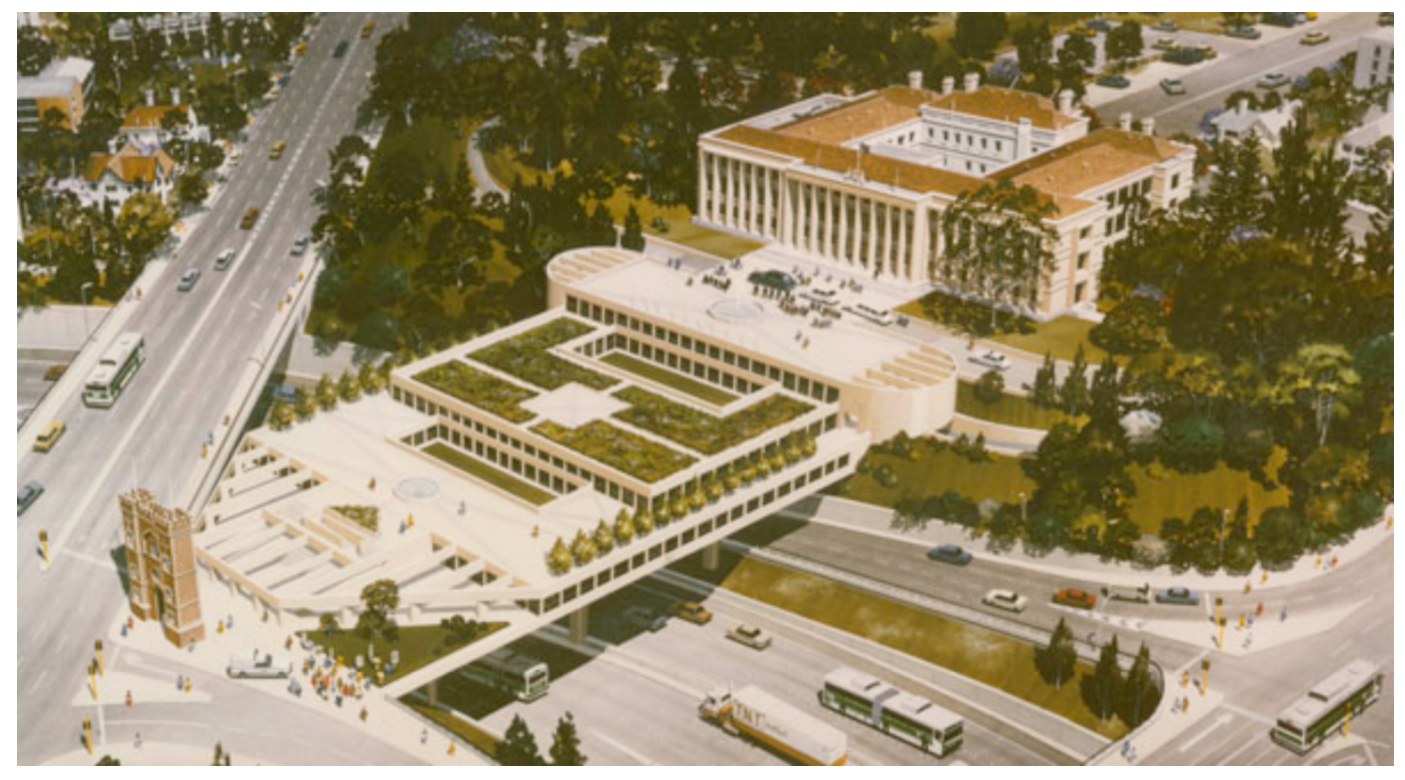

Figure 7: Proposed land bridge, 1988

Source: Visions for Parliament House: 1900-2004 \& Beyond, 1988; courtesy of the Parliament of Western Australia ${ }^{44}$

Where the dominant suburban form of Perth stretches north-south along the coast, the city itself runs west-east. The western entry to the city is dominated by Mont Eliza and now, as we have just seen, has Parliament House overlooking the city down St George's Terrace. The north of the city was dominated by a series of wetlands, known as the Perth Wetlands, most of which have now been drained, that had made suburban sprawl there difficult. The south of the city is marked by the Swan River. It is not surprising then that people in Perth tend to ask if one lives north or south of the river. With the Causeway, first completed in 1843 with the present version dating from 1952, as the first, and for a long time the only, means in Perth of crossing from north to south of the river, the river has always been a significant boundary to the city's development. For a long time the eastern entry to the city went unmarked. Crossing the Causeway one simply found oneself at a roundabout where Riverside Drive, Adelaide Terrace, which becomes St George's Terrace, and Hay Street meet. From 1975 the eastern entry into the city has been dominated by the Police Headquarters. Thus, as the state became more authoritarian so the built environment expressed this. Government looked down across the city from Mount Eliza at the western end while the entry to the city from the eastern end has been dominated by the Police Headquarters. This building, 
though, looks outwards, as if surveilling those who might enter-perhaps keeping out, and at least keeping an eye on, those who might criticise the government of Western Australia.

-SURVEILLANCE

Reviewing the images in his book A City and Its Setting, George Seddon writes that Perth 'was perceived almost as a walled city, perhaps because the sense of clear definition was psychologically necessary in such a vast and remote wilderness.' 45 The boundedness of Perth city lends itself to another image, that of a prison. Seddon comments on this image in Western Australian writers:

Like Dorothy Hewett, Randolph Stow also made his escape from the narrowly provincial city he satirised, and, perhaps also therefore subscribes to the metaphor of 'the glass prison'-of an oppressive and petty society in a setting of natural beauty and apparent tranquillity. 46

The reference to a glass prison is to Philip Masel's 1937 novel set in Perth, In a Glass Prison. Entering from the eastern gateway, the Police Headquarters reinforces this image. It also, of course, presents the counter idea: if you've done nothing wrong you have nothing to worry about. If this is the case Perth will not feel like a prison but, rather, a sanctuary guarded by the Police Headquarters and overseen by Parliament House. This is the essence of the structure of surveillance.

Michel Foucault discusses 'an order published at the end of the seventeenth century, [which contains] the measures to be taken when the plague appeared in a town. ${ }^{47}$ He writes:

Inspection functions ceaselessly. The gaze is alert everywhere: 'A considerable body of militia, commanded by good officers and men of substance', guards at the gates, at the town hall and in every quarter to ensure the prompt obedience of the people and the most absolute authority of the magistrates, 'as also to observe all disorder, theft and extortion'. At each of the town gates there will be an observation post; at the end of each street sentinels. ${ }^{48}$

Here, there are not yet police, they won't exist for another century or so, but militia guarding the entrance to the city. Keeping out, one presumes, those likely to be carrying the plague but, also, keeping a close watch on the citizens of the city, 
making sure, with a show of force, that they do not step out of line. Foucault considers this to be the beginning of the surveillance system he identifies as a decisive aspect of modern life. However, it also describes well the role of the Police Headquarters building-all the more so if we think of the plague itself as a metaphor, now for the evils which Western Australians believe infest other cities and from which Perth needs to be protected.

For Foucault the role of surveillance is epitomised in Jeremy Bentham's ideal prison, the Panopticon. Having outlined the panoptic form, the organisation of confinement, Foucault adds: 'All that is needed, then, is to place a supervisor in a central tower.' 49 The idea is that the prisoners do not know when they are being surveilled so they behave as if they are always under surveillance. In the Police Headquarters building we have the tower, though it is not central. It is placed, as we have seen, at one of the two gateways into the city. Foucault argues that:

the major effect of the Panopticon [is] to induce in the inmate a state of conscious and permanent visibility that assures the automatic functioning of power. So to arrange things that the surveillance is permanent in its effects, even if it is discontinuous in its action; that the perfection of power should tend to render its actual exercise unnecessary. ${ }^{50}$

Built facing the Causeway, the windows of the Police Headquarters look out over the traffic coming into the city. It is a permanent reminder to those entering Perth that the police are, or, as with the Panopticon, may be, watching. The earlier use of the Perth Girls' School building, with its high-set position surveilling the surrounding district was a step in this direction. One favourite spot for the use of police 'booze buses', the vans carrying breathalyser equipment, is on the Causeway. When the buses are there, the citizens of Perth entering or leaving the city by its eastern gate know for sure they are being surveilled. ${ }^{51}$

In Romania's capital, Bucharest, the dictator Nicolae Ceausescu built an immense and monumental palace that was intended to serve as both a residence for his family and as the seat of government. It stands at the end of a long boulevard deliberately designed to be both wider and longer than the Champs Elysées. Renata Salecl comments:

Ceausescu's Panopticon adopts a ... traditional surveillance strategy. From the palace, which sits on an artificial hill ... one has a view over a large part 


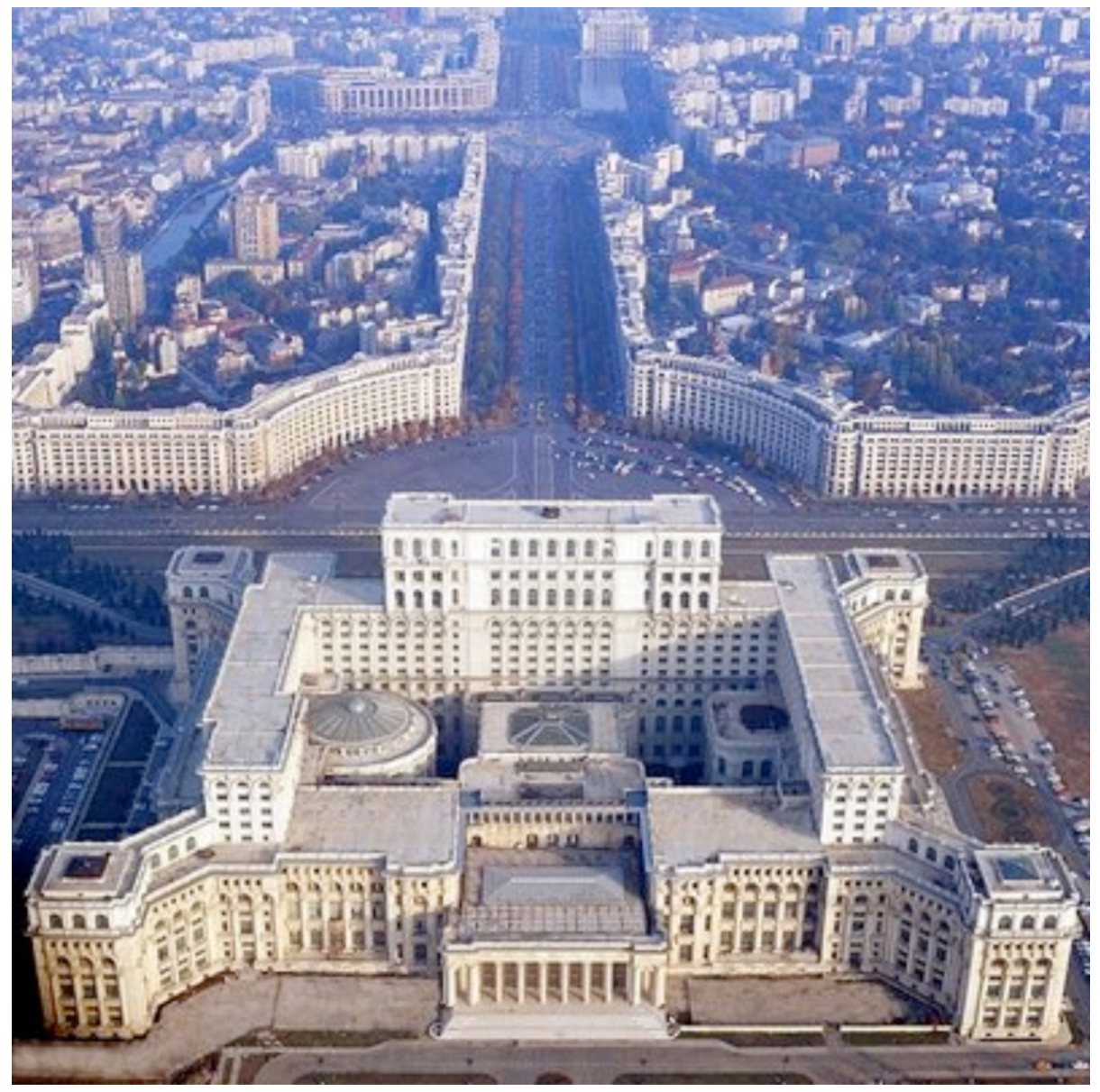

Figure 8: Ceausescu's People's Palace; view down Victory of Socialism Boulevard

Source: 'The People's Palace: Ceausescu's Lasting, Loathed Legacy', in Bucharest-Life.com, n.d.; courtesy of Local Life ${ }^{52}$

of the city. It is significant that the palace, observed from the avenue, appears to have no entrance, there are only numerous windows, which give the impression of an omnipresent gaze. 53

I only want to make a structural comparison with the Perth Police Headquarters. The Headquarters are not on a hill, though the Girls' School building is and, as we have seen, so is Parliament House. Parliament House surveills the city, and in particular the business district, as it looks down St George's Terrace. However, the Headquarters does stand at the end of a long and moderately straight road. While not positioned immediately at the end of the Causeway, there is certainly a sense of being surveilled as one drives closer to the building. The Causeway leads out of Shepperton Road which in turn joins Albany Highway, the road that leads some four 
hundred kilometres down to Albany, the port city on the south coast in the most populous area of Western Australia outside of Perth. It is the south, then, that the Police Headquarters surveils.

Its back is to the north, the land of resource development where, as we have seen, Western Australia's premiers have placed development ahead of equitable law, and where the role of the police remains to protect the interests of resource companies rather than the rights of the Indigenous people. One purpose in referencing Ceausescu's folly is to note how authoritarian states often build panoptic edifices with long approach roads. Albert Speer's plan for a rebuilt Berlin to suit Hitler's ambitions, Welthauptstadt Germania, would have had a boulevard five kilometres in length at the end of which would have been the Volkshalle, the People's Hall. The significance of these boulevards is to magnify the awe of government in people approaching down them. Again, my point is about structure and similarity. Approaching the city of Perth across the Causeway one is always reminded of the power of the Western Australian police. As Western Australia's government became more authoritarian so it created a built environment that has resemblances to other authoritarian built environments. Feilman's argument for the retention of the Pensioner Barracks arch was well made.

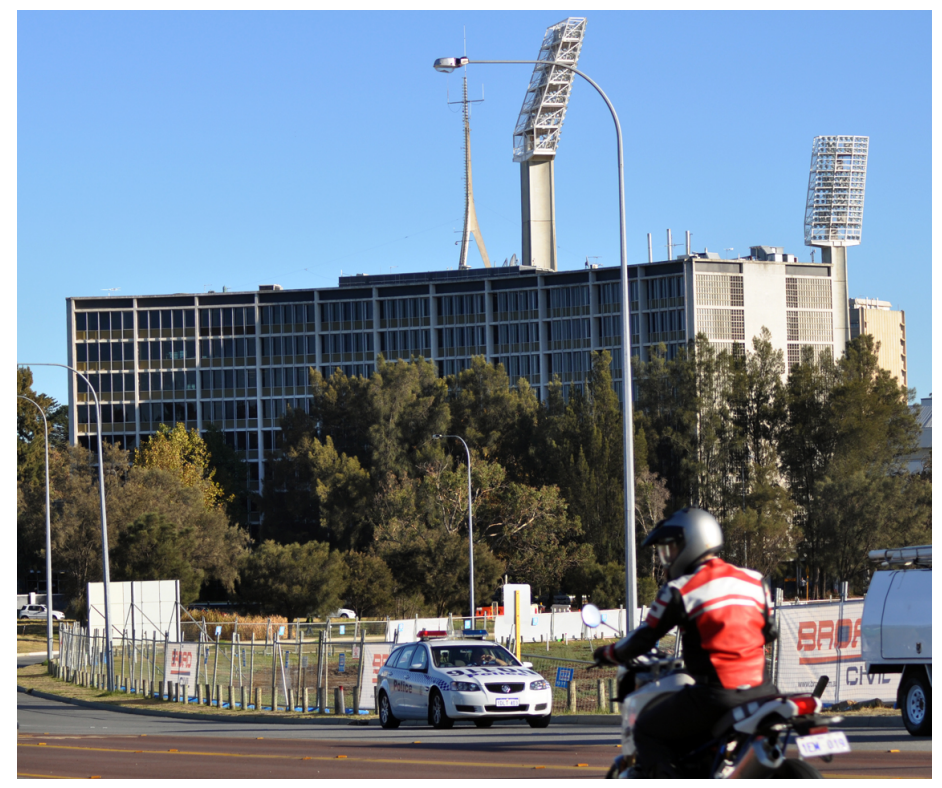

Figure 9: Photo taken from Causeway; note police car Photographer: Panizza Allmark 
In 1989 Perth established a city security plan. Among other things this involved putting in place:

the first major shopping mall video surveillance system in Australia. Fortyeight cameras, with the ability to tilt, pan or zoom over 360 degrees, were mounted about three metres above the pavement, monitoring the activities of thousands of people who walked through the city each day. A central control room, located next to a community post in the Town Hall and staffed by five officers, achieved twenty-four hour surveillance. 54

Over the years the numbers of cameras and their placings across the Perth metropolitan area have increased. Clive Norris and Barry Armstrong argue:

What is crucial to understand is that the move from a mass surveillance society towards a maximum surveillance society is only partly dependent on the spread of cameras. Cameras, or other sensing devices, are a necessary, but not sufficient, condition in the move towards panopticisation. It is the ability to store, sort, classify, retrieve and match which is all important. 55

The forms of surveillance in Perth, as in other major cities have been transformed. The cameras were the harbinger of a much more extensive and closely woven surveillance system. This includes, for example, facial recognition abilities as well as the means to monitor bank accounts, shopping practices and more. The SIM cards of mobile phones enable the owners of the phones to be tracked. These new systems depend increasingly on computers and the digitalisation of information.

In 1975, when it was opened, the Police Headquarters building was state of the art, the centre of a successful modern surveillance system. By the early twenty-first century means of surveillance were being transformed. When the Commonwealth Heads of Government Meeting (CHOGM) was held in Perth in 2011 the entire operation was monitored from a $\$ 5$ million command centre in the suburb of Maylands. During the three-day event, around one hundred officers continuously watched 'video screens spanning a 30-metre long wall and rolling CCTV footage from fixed and mobile devices throughout the city'. ${ }^{56}$ Other computerised databases identified people on file as possible troublemakers. They were monitored and their homes were searched. The Police Headquarters building had already begun to seem dated. Indeed, it had been put on the Western Australian Heritage Register in 2003. 
In 2006 moves started to build a new police headquarters back in Northbridge on the corner of Roe and Lake streets. The $\$ 80$ million complex will replace the 'antiquated facilities at East Perth'.57 The then Police Minister, John Kobelke, said: 'The jewel in the crown of the complex will be the Perth Police Centre, which will bring together almost 440 police officers and administration staff from police headquarters and Curtin House.'58 Work on the new complex began in 2009. By then the estimated cost had increased to $\$ 113$ million. There will be no return to communal policing. The new headquarters will take full advantage of digital surveillance systems.

In 2011 work began to transform the area on the river across the road from the Police Headquarters building. The Metropolitan Redevelopment Authority describes the new project in these terms:

The MRA's vision for Riverside is to transform the eastern gateway to Perth by creating a cosmopolitan waterfront community and tourist destination with a range of entertainment, commercial, retail, civic and residential uses that take advantage of its unique location. The project will attract $\$ 2.6$ billion in investment and bring almost 6000 new residents into the area and attract another 1700 workers. 59

The eastern gateway will present a postmodern Perth of consumerism and recreation-emphasising the fruits of the long resource development boom. The Burswood Entertainment Complex, including the casino, will remain on the southern side of the river and the WACA, redeveloped but still a sports ground, will remain in its present location. A new ground for Australian Rules football will be built near the entertainment complex. We might think again of bread and circuses. There is yet to be a decision as to what to do with the Police Headquarters building. However, it is unlikely to continue to be used by the police. With the massive changes in technology that have resulted in maximum surveillance, there is no need for a building such as the Police Headquarters. The people of Western Australia will continue to be surveilled, indeed that surveillance has increased, but it will no longer be so obvious. The Police Headquarters building will remain but now as an integral part of Perth's modern heritage and situated within a new residential and entertainment area. 
Jon Stratton is Professor of Cultural Studies at Curtin University. He has published widely in cultural studies, Australian studies, Jewish studies and popular music studies. His most recent book is Uncertain Lives: Culture, Race and Neoliberalism in Australia (2011).

-Notes

${ }^{1}$ Louis Althusser, in 'Ideology and Ideological State Apparatuses' (in his collection Lenin and Philosophy and Other Essays, trans. Ben Brewster, Monthly Review Press, New York, 1971, p. 174) writes: 'I shall then suggest that ideology "acts" or "functions" in such a way that it "recruits" subjects among the individuals (it recruits them all), or "transforms" the individuals into subjects (it transforms them all) by that very precise operation which I have called interpellation or hailing, and which can be imagined along the lines of the most commonplace everyday police (or other) hailing: "Hey, you there!"'

2 The Police Headquarters building goes by many names. The Heritage Council of Western Australia knows it as the Western Australian Police Service Complex.

3 Patrick Joyce and Tony Bennett, 'Material Powers: Introduction' in Material Powers: Cultural Studies, History and the Material Turn, eds Tony Bennett and Patrick Joyce, Routledge, London, 2010, p. 2.

${ }^{4}$ Joyce and Bennett, p. 5.

5 I have discussed the 'Perth experience' elsewhere in the context of popular music, see, for example, the chapters on Perth in Jon Stratton, Australian Rock: Essays on Popular Music, Network Books, 2007. 6 'Western Australian Police Service Complex', in Government of Western Australia: The State Heritage Office, 14 February 2003, Register of Heritage Places-Assessment Documentation, p.7 $<$ http://register.heritage.wa.gov.au/PDF_Files/UZ\%20Reg/WA\%20Police\%20Serv\%20comp\%20(P).PDF>.

7 <http://en.wikipedia.org/wiki/File:Rko.JPG>.

8 When he opened the building on 23 April 1975, Charles Court noted: 'The new Police Headquarters Building, overlooking the eastern gateway to the City of Perth, brings with it a new era of high speed communication for the Police Department in Western Australia', quoted in 'Western Australian Police Service Complex', p. 6.

9 On this history, see Peter Conole, 'Northbridge: Policing Revealed', in Department of the Premier and Cabinet: The Northbridge History Project, 18 May 2008, NBHDC-0861,

$<$ http://www.northbridgehistory.wa.gov.au/index.cfm?event=document\&documentName=nbhdc0861.pdf>.

10 'Art Gallery Administration Building: Formerly Police Barracks, Police Headquarters and CIB Building', in Government of Western Australia: The State Heritage Office, 24 March 2000, Register of Heritage Places - Assessment Documentation, p 2.

$<$ http://www.google.com.au/url?sa=t\&rct=j\&q=art\%20gallery\%20administration\%20building\%20he 
ritage $\% 20$ documentation \&source=web\&cd=1\&cad=rja\&sqi=2\&ved=0CEcQFjAA\&url=http $\% 3 \mathrm{~A} \% 2 \mathrm{~F} \% 2$ Fregister.heritage.wa.gov.au\%2FPDF_Files\%2FA\%2520-\%2520A-

D\%2FArt\%2520Gallry\%2520Admn\%2520Bldg(P-

AD.PDF\&ei=tzcvULHpAaiuiQfPt4DgDg\&usg=AFQjCNGRborhTGDVLPWTQF8LLRf2SGfs- $w>$.

$11<$ http://henrietta.slwa.wa.gov.au/search $\sim$ S6?/XJames+Street+Police+Barracks\&searchscope

$=6 \&$ SORT $=$ D $/$ XJames + Street + Police + Barracks \&searchscope $=6 \&$ SORT $=$ D\&SUBKEY=James + Street + Polic

e+Barracks $/ 1 \% 2 \mathrm{C} 6 \% 2 \mathrm{C} 6 \% 2 \mathrm{CB} /$ frameset\&FF=XJames+Street+Police+Barracks\&searchscope=6\&SORT $=\mathrm{D} \& 2 \% 2 \mathrm{C} 2 \% 2 \mathrm{C}>$.

12 'Perth Girls' School (fmr)', in Government of Western Australia: The State Heritage Office, 28 February 1995, Register of Heritage Places - Assessment Documentation, p.2.

<http://www.google.com.au/url?sa=t\&rct=j\&q=perth\%20girls\%20school\%20\%20heritage\%20docum entation \&source=web\&cd=1\&cad=rja\&sqi=2\&ved=0CEoQFjAA\&url=http $\% 3 \mathrm{~A} \% 2 \mathrm{~F} \% 2 \mathrm{Fregister}$. heritag e.wa.gov.au\%2FPDF_Files\%2FP-Q\%2520-\%2520A-D\%2FPerth\%2520Girls\%2520School\%2520(P-

AD).PDF\&ei=hjgvUKvEA-qQiAf35oDgBA\&usg=AFQjCNGH4tNIiBiXkomh62CNe2oI0So2BA>

13 'Perth Girls' School (fmr)', p. 5.

14 On the history of Australian policing, see Mark Finnane, Police and Government: Histories of Policing in Australia, Oxford University Press, Melbourne, 1994.

15 Christopher Corns, 'Policing and Social Change', The Australian and New Zealand Journal of Sociology, vol. 24, no. 1, 1988, p. 35.

16 Conole, Northbridge: Policing Revealed'.

17 Chris Cunneen, Conflict, Politics and Crime: Aboriginal Communities and the Police, Allen \& Unwin, Sydney, 2001, p. 49.

18 Stephen Hester and Peter Eglin, A Sociology of Crime, Routledge, London, 1992, p. 153.

19 Ibid., p. 153.

20 J.E. Thomas and Alex Stewart, Imprisonment in Western Australia: Evolution, Theory and Practice, University of Western Australia, Nedlands WA, 1978, p. 197.

21 These figures come from M.F. Farquhar, 'The Social Challenge in the Summary Court', Australian Journal of Forensic Sciences, vol. 4, no. 1, 1971, pp. 33-43.

22 Quinton Beresford, Rob Riley: An Aboriginal Leader's Quest for Justice, Aboriginal Studies Press, Canberra, 2006, p. 98.

23 William J. Lines, Taming the Great South Land: A History of the Conquest of Nature in Australia, Allen \& Unwin, Sydney, 1991, p. 209.

${ }^{24}$ Brian Head, 'From Deserts the Profits Come: State and Capital in Western Australia', The Australian Quarterly, vol. 57, no. 4, 1985, p. 373.

25 Ibid., p. 372.

26 Lines, p. 209.

27 Jolly Reid, Marksy: The Life of Jack Marks, Read Media, South Fremantle WA, 1998, p. 22. 
28 Peter Conole, Protect and Serve: A History of Policing in WA, Western Australian Police Historical Society, Scarborough WA, 2002, p. 343.

${ }^{29}$ Jenny Gregory, City of Light: A History of Perth Since the 1950s, City of Perth, Perth, 2003, p. 193.

30 Quoted in Conole, Protect and Serve, p. 345. In Queensland, in September 1977, Bjelke-Petersen followed Court's lead forcing any group who wanted to march to get a permit from the Queensland Police Commissioner. Bjelke-Petersen was even more blunt than Court stating: 'The day of the political street march is over ... Don't bother to apply for a permit.' Quoted in Lines, p. 250.

31 Lines, p. 250.

32 Ibid.

33 Ibid., pp. 249-50.

34 Ibid., p. 209.

35 Stephen Hawke and Michael Gallagher, Noonkanbah: Whose Land, Whose Law, Fremantle Arts Centre Press, Fremantle WA, 1989, p. 15.

36 Paul Kaplan, 'Noonkanbah 30 Years On-WA still a racist state', in Green Left, 25 September 2010, $<$ http://www.greenleft.org.au/node/45483>.

37 Tom Wolfe, From Bauhaus to Our House, Farrar Straus Giroux London, Sphere Books Ltd, New York, 1981, p. 40.

38 Darryl Haltenhauer, 'The Rhetoric of Architecture: A Semiotic Approach', Communication Quarterly, vol. 32, no. 1, 1984, p. 75 .

39 Ibid., p. 76.

${ }^{40}$ Andrea Witcomb and Kate Gregory, From the Barracks to the Burrup: The National Trust in Western Australia, UNSW Press, Sydney, 2010, p. 240.

$41<$ http://en.wikipedia.org/wiki/File:Barracks_Arch.jpg>.

42 Allan Peachment, 'WA Inc', in The Business of Government: Western Australia 1983-1990, ed. Allan Peachment, Federation Press, Annandale NSW, 1991, p. 191.

43 It is perhaps worth noting that it was also the Burke government that established the Burswood Island Casino, as it was known when it was opened on 30 December 1985, on the south side of the eastern gateway. At that time this was the largest casino in Australia. It could be argued that the Burke administration introduced gambling to Western Australian government by developing the close business relationships identified as WA Inc. and literally introduced gambling to the state in the Burswood casino. Had the projected bridging area been built from Parliament House to St George's Terrace, the built environment would have expressed each of these gambling-related initiatives at each city gateway.

44 <http://www.parliament.wa.gov.au/visions/1980s.htm>.

45 George Seddon, A City and Its Setting: Images of Perth, Western Australia, Fremantle Arts Centre Press, Fremantle WA, 1986, p. 263.

46 Ibid., p. 33. 
${ }^{47}$ Michel Foucault, Discipline and Punish: The Birth of the Prison, trans. Alan Sheridan, Vintage Books, New York, 1979, p. 196.

48 Ibid., p. 196-7.

49 Ibid., p. 201.

50 Ibid., p. 202.

51 The importance of the Police Headquarters building/Causeway connection was illustrated in February 2012 when a group of Indigenous protesters established a Noongar tent embassy at Matagarup on Heirisson Island. Heirisson Island sits in the middle of the Swan River and is crossed by the Causeway. The group centred around Noongar elders were concerned about Native Title negotiations that were concluding between the West Australian government and the South West Aboriginal Land and Sea Council. The embassy, and reactions to it, brought together issues related to the Noongar population, the police, and the government. Placing the embassy at Matagarup highlighted these links. Thor Kerr and Shaphan Cox have written on the media reportage of the tent embassy in Thor Kerr and Shaphan Cox, Setting Up the Nyoongar Tent Embassy: A Report on Perth Media, eds Robert Briggs, Niall Lucy and Steve Mickler, Ctrl-Z Press, Perth, 2013.

52 <http://www.bucharest-life.com/bucharest/palace-of-parliament>.

${ }^{53}$ Renata Salecl, 'Where is the Center?', 3 June 2000, < http://www.westfaelischer-

kunstverein.de/uploads/pdf/2000_realplaces/salecl.pdf>.

54 Gregory, p. 301.

55 Clive Norris and Gary Armstrong, The Maximum Surveillance Society: The Rise of CCTV, Berg, Oxford, 1999, p. 219.

56 Courtney Trenwith, 'CHOGM police unveil country's most advanced command centre”, in WAToday, 14 October 2011, < http://www.watoday.com.au/wa-news/chogm-police-unveil-countrys-mostadvanced-command-centre-20111014-1lozn.html>.

57 Jim Kelly, 'Police get new $\$ 80$ m Northbridge station', in PerthNow, 22 November 2006,

<http://www.perthnow.com.au/news/western-australia/police-get-new-80m-northbridgestation/story-e6frg13u-1111112573081>.

58 Ibid.

${ }^{59}$ Metropolitan Redevelopment Authority, <http://www.mra.wa.gov.au/Projects/Riverside/Aboutthe-Project/>. 